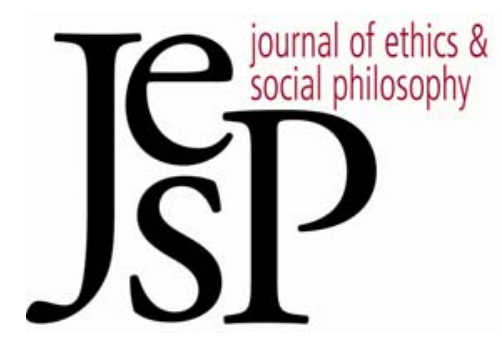

\title{
Could Morality Have a SourCE?
}

\author{
By ChRIs HEATHWOOD
}

Journal OF ETHICS \& SOCIAL PHILOSOPHY

Vol. 6, No. 2 | APRIL 2012 URL: WWW.JESP.ORG COPYRIGHT (C) CHRIS HEATHWOOD 2012 


\title{
Could Morality Have a Source?
}

\author{
Chris Heathwood
}

\section{$\mathrm{I}$} T IS A COMMON IDEA THAT MORALITY, or moral truths, if there are any, must have some sort of source. If it is wrong to break a promise, or if our fundamental moral obligation is to maximize happiness, these facts must come from somewhere - perhaps from human nature, or our agreements, or God. Such facts cannot be ungrounded, floating free.

I not only deny this, I believe its opposite. If we look more closely at the moral theories that are supposed to be paradigm examples of theories under which morality has a source, we will see that these theories, too, posit ungrounded moral truths. This is not only interesting in its own right, it is important because it is sometimes thought to be an unacceptable feature of moral realism that, according to it, morality has no source, and so if we are moral realists, we must believe in brute, inexplicable moral truths. Since, as I will try to show, anyone who believes in moral truths at all must believe that there are brute and inexplicable ones, this is no objection to moral realism. ${ }^{1}$

Moral realism is here the view that (i) some things have moral properties (properties such as being morally wrong or being intrinsically good) and (ii) when something has a moral property, that property is not had in virtue of the attitudes that any observers (actual or hypothetical) have towards the thing, or in virtue of the practices they engage in concerning it. In other words, these moral properties are objective, or "stance independent." 2 Moral constructivism is the view that things do have their moral properties in virtue of such attitudes or practices.

Surely the most popular answer, historically speaking, to the question, "Where do moral truths come from?" has been, "God." As Locke wrote, the "true ground of morality ... can only be the will and law of God" (1690, I.III.6). Some writers still find the theistic answer compelling. William Lane Craig, for instance, holds that "moral values cannot exist without God," and complains that "Atheistic moral realists seem to lack any adequate foundation in reality for moral values, but just leave them floating in an unintelligible way" (2004: 18, 19). Craig is here making the argument against realism to which I just alluded.

Other philosophical traditions appeal to other sources. Sentimentalists claim to "ground morality in human nature," in particular, in our tendency to

\footnotetext{
1 By a "truth," I simply mean the kind of thing, whatever it is, that we can believe, or that is expressed by declarative sentences, and is in fact true. Many philosophers would call them "true propositions." We could also call them "facts," so long as we do not hold a relatively sparse view of facts, according to which, for example, although it is true that if you make a promise you ought to keep it, there is no fact in the world to the effect that if you make a promise you ought to keep it. For stylistic variation, I sometimes use the term "fact."

2 This phrase is due to Milo (1995: 182, 190-93). See also Shafer-Landau 2003: 15-17 and Huemer 2005: 1-7 for the same sort of definition of moral realism.
} 
approve and disapprove of certain kinds of behavior and character. ${ }^{3}$ Lara Denis (2008: \$2) uses this and similar expressions in her characterization of Hume's theory:

Hume takes morality to be independent of religion. In his ethical works, he clearly tries to ground morality in human nature, and to make a case for morality that stands just as well without a theistic underpinning as with one. ... [B]y basing morality in sentiment, he excludes God as a moral assessor.

Contractarians agree that morality is grounded in some way in us, but not in our nature; rather, our moral obligations derive from the agreements we have made, or would make, with each other. For example, according to Ronald Milo (1995: 184),

It is true (or is a fact) that a certain kind of act is wrong, for example, just in case a social order prohibiting such acts would be chosen by rational contractors under suitably idealized conditions.

Ideal observer theories hold that the truths of morality come from the attitudes of an ideal observer (Firth 1952). For some Kantians, "our autonomy is the source of obligation" (Korsgaard 1996: 104). Each of these views, including the divine-based theory, is a form of constructivism about morality. 4

By contrast, "the realist must," as Russ Shafer-Landau puts it, "say of the moral standards she favors that they just are correct - not in virtue of their being selected or created by anyone, but simply correct" (2003: 46). Shafer-Landau, himself a realist, presents our related argument against realism as follows:

[One] anti-realist argument relies on what is meant to be an embarrassing question for realists: what makes moral judgments true? ... Realists don't have any general answer to this question. Constructivists do. They can point to some person(s), actual or idealized, whose attitudes are responsible for fixing the truth. ... It might be an ideal observer, or one's social group, or oneself (2003: 45).

The objection is not the epistemological one concerning how the realist could come to know moral facts or principles, given that they are not constructed. It is a metaphysical objection concerning where these facts and

\footnotetext{
3 By "sentimentalism," I mean cognitivist sentimentalism, as opposed to the expressivist sentimentalism of, say, Simon Blackburn. My theses in this paper are conditional on the assumption that there are moral truths in the first place; thus, I set aside metaethical expressivism, as well as Blackburn's quasi-realism, which understands "moral truth" to mean something different than I mean by it (not the sort of thing that we believe).

${ }^{4}$ Not all divine-based theories are forms of constructivism. On one kind of divine-based theory (e.g., Adams 1999), a thing is good to the extent that it resembles God. This is a form of realism about goodness. In footnote 11, I explain how my main point about constructivism would apply to this theory.
} 
principles come from, or what makes them correct, given that they are not constructed.

These issues arise for a related topic in ethics as well: the internalism/externalism debate about normative reasons. Reasons internalism, which corresponds to constructivism, is roughly the view that whenever a person has a reason to do something, this is grounded in her (possibly idealized) desires (Brandt 1979, Williams 1981). Reasons externalism, which corresponds to realism, is the view that at least some of our reasons are grounded in external states of the world, such as objective evaluative facts, rather than in our desires (Quinn 1993, Parfit 2001). One argument against internalism claims that, given internalism, reasons have an objectionably arbitrary foundation, since the desires that ultimately explain our reasons are, on this view, desires that we have no reason to have. Alan Goldman, a reasons internalist, counters that externalism faces a corresponding problem - exactly the problem that Shafer-Landau and Craig allege for moral realism:

To be fair, we must compare the fact that the internalist can provide no reasons for having the fundamental concerns that we do ... with the fact that the externalist can provide no explanation of objective values (they are simply brute normative facts) (Goldman 2006: 484).

Shafer-Landau's response to the objection is to admit that constructivists do deliver the goods here while realists do not, but to point to other domains in which we accept that there are laws without lawmakers, such as logic, math and physics (2003: 45). But this "companions in guilt" response may be unpersuasive to those who believe that there are too many disanalogies between ethics on the one hand and logic, math and physics on the other.

My response relies on no such analogies. It is that constructivists do not deliver the goods in the first place. They, too, must accept some moral facts as brute. ${ }^{5}$ My first thesis is thus that, concerning the question of whether morality has a source, constructivists have no advantage over realists.

My second thesis is that morality in fact couldn't have a source. This second thesis might seem to fail if reductionism in ethics is true. So I will explain why it seems that even if reductionism is true, not all moral truths will have a ground. Thus, both constructivism and reductionism are on a par with nonreductive realism concerning the question of whether morality has a source. Assuming that there are moral facts at all, then, even if reductionism or constructivism is true, some of them must go unexplained.

\section{What is the issue?}

When I speak of the question of where morality comes from, I of course do not mean to be talking about the causal, sociological question of the origin of

5 Or, if there is a way for constructivists to ground their fundamental moral truths, this way will be available to realists as well (see footnote 9 below). 
the moral code that prevails in our culture, nor of the fact (if it is a fact) that human cultures everywhere subscribe to some moral scheme or other. Nor are we talking about morality's epistemological ground, or the question of how we can know moral facts. I instead mean to be inquiring into the following noncausal, philosophical question: Assuming some moral claims are true, what makes them true? What grounds them? In virtue of what are they true? This grounding relation is an explanatory relation in that when one fact is grounded in another, or made true by it, the latter explains the former - in at least one way of explaining. To clarify further, I am not asking which concrete things or stuff in the world makes these truths true, but rather which other truths make these truths true. The claim that some moral truth has no propositional grounding (our issue here) is compatible with the idea that it has some concrete grounding (such as in the form of some concrete event, fact, or state of affairs in the world). ${ }^{\circ}$

The opposite of a moral truth having a ground in this sense is the idea of a moral truth being brute. We can get a grip on what it is for a moral truth to be brute by reviewing a moral system on which this phenomenon is especially perspicuous: the theory of prima facie duties of W. D. Ross. Ross takes as fundamental the notion of a prima facie moral obligation, which one has when one has a moral reason, but an overridable one, to perform some action. According to Ross' theory, whenever it is true that some person has an all-thingsconsidered moral obligation - "a duty proper" (1930:19) - this is true in virtue of the fact that the person has a prima facie obligation to do something and has no conflicting prima facie obligations that match or outweigh it (1930: 41).

Consider, for illustration, Ross' view about promises. Suppose I have promised to drive a friend to the airport. According to Ross, I therefore have a prime facie obligation to do it (and will have an all-things-considered obligation to do it so long as there are no competing and outweighing prima facie obligations in play). I have this prima facie obligation because the act in question is an act of promise-keeping, and there is a general prima facie duty to keep one's promises (1930: 21). In other words, the following is a true moral principle:

\section{Rossian principle}

If a person has made a promise to perform some act then the person has, in virtue of that, a prima facie moral obligation to perform that act.

In still other words, promise-breaking is a wrong-making feature of actions. What's more, this principle, according to Ross, expresses a basic prima facie

${ }^{6}$ The relation discussed here is a species of the "explanatory dependence" of Correia (2008). 7 The "in virtue of that" is added to reflect the fact that moral principles like the Rossian principle are meant to be explanatory. It is not just that whenever you have made a promise, it also happens to be that you are under an obligation; it is that your having made the promise explains your being under the obligation. The obligation is grounded in the promisemaking. 
duty, a basic moral fact. This fact, Ross would say, has no source, and cannot be explained in terms of any allegedly more basic truth, such as, for example, the principle of utility. In a striking passage (1930: 29-30), Ross declares,

The moral order expressed in these propositions [such as the principle above] is just as much part of the fundamental nature of the universe ... as is the spatial or numerical structure expressed in the axioms of geometry or arithmetic. ${ }^{8}$

As we have noted, some find this picture incredible. Craig (2004: 19) expresses this common view as follows:

Atheistic moral realists affirm that moral values and duties do exist in reality and are not dependent upon evolution or human opinion, but they insist that they are not grounded in God. Indeed, moral values have no further foundation. They just exist. I must confess that this alternative strikes me as incomprehensible.

How, these critics might say, could that fact (the Rossian principle above) be a fundamental fact of reality, alongside such other putatively and more acceptably basic facts as the law of noncontradiction, the fact that there is something rather than nothing, and the fundamental laws of physics? It can be tempting to ask, Who says that if you make a promise, you have to keep it? Where did this rule come from?

\section{How constructivism is like Rossian realism}

Some believe that constructivists can avoid all this because, according to them, this truth about the duty to keep promises (which, for our purposes, we will assume is one of the truths of morality) can be, or has been, constructed. Defenders of the view that God is the source of morality can say that the Rossian principle is true in virtue of the fact that God has commanded us to keep our promises. Sentimentalists can claim that we ought to keep our promises because we tend to disapprove of promise-breakings, or tend to approve of the character trait of fidelity. And contractarians can say that promise-breaking is wrong because it would be rational for us to agree to live by a set of rules that forbids it.

Maybe one of these explanations is correct, or maybe some other form of constructivism is correct. I am not disputing that here. Rather, I am claiming that none of the sample approaches just given - or any other possible constructivist answer - can provide a source for all moral truths after all.

The reason is straightforward: There is still the constructivist theory itself to deal with. What grounds this theory? Such a theory can provide the source for moral facts such as Ross' principle. It may succeed in grounding all everyday moral truths, particular and general. But there will always be one moral truth

8 Similar views were held by Samuel Clarke (1732: 176-240), Ralph Cudworth (1731, ch. 2, \&

4) and Richard Price (1787, ch. 1, \3). 
that is left out: the theory itself. God may be the source of the fact that if you make a promise, you ought to keep it, but what about the following moral claim, which divine-based constructivists believe to be a truth?

DCT: An act is morally obligatory iff, and because, God commands it.

This claim, like the Rossian principle above, is a moral claim. For it says the same as the following conjunction:

if an act is morally obligatory, then God has commanded it, and if God has commanded some act, then the act is, in virtue of that, morally obligatory.

The second conjunct is structurally identical to the Rossian principle. Both are of the following form: If such-and-such nonmoral condition holds, then such-and-such moral condition holds in virtue of that. Since the Rossian principle is surely a moral claim, so is the DCT. ${ }^{9}$

What, then, is the source of the moral truth that is the DCT (assuming it is a truth)? At least in the theistic case, it is tempting to explore whether, just as God is the source of the Rossian moral principle above, God is likewise the source of DCT itself. But, depending on the details, this kind of reply either faces a regress or is viciously circular.

As all parties should agree, if God is the source of the Rossian principle, there will be a further principle along the lines of that if God commands some act, then we are morally obligated, in virtue of that, to do it (this is the second conjunct of the second formulation of the DCT above). This suggests that the following schema is true: In order for concrete object $\mathrm{X}$ to be the source of some moral truth $\mathrm{M}$, there must be some further principle $\mathrm{P}$ to the effect that the truth of $\mathrm{M}$ is grounded in some truth about $\mathrm{X}$. (In the above, $\mathrm{X}=$ God, $\mathrm{M}=$ the Rossian principle and $\mathrm{P}=$ DCT.) But then in order for God to be the source of the moral truth that is DCT, a further principle must be true, something like the following "meta" divine command theory:

\footnotetext{
9 In a similar vein, Dworkin notes that the constructivist theory that "what makes an act morally wrong is that contemplating that act in fact produces a particular kind of reaction in most people" "does take sides in actual or potential substantive [moral] disputes" (1996: 102, 101). If the Rossian principle is somehow not a moral claim, then moral realism can provide a source for all moral truths after all - thus giving constructivism no advantage (as according to my first thesis). For the Rossian principle, together with the nonmoral claim that some person has made some promise, will ground the moral claim that this person has a prima facie obligation to keep the promise. Other kinds of moral truth, such as about duties concerning reparations, justice, non-maleficence, etc. could be similarly grounded.
} 
mDCT: If God declares that DCT is true, then, and in virtue of that, DCT is true.

But, although it does not wear this status on its sleeve, mDCT is a moral claim. For it says that a certain moral claim - DCT - will be true if a certain condition is satisfied. And this, again, is structurally the same as the initial Rossian claim that if you make a promise, you morally ought to keep it. Thus, it too will need a source if we are going to avoid any groundless moral facts. We could posit a meta-meta-DCT, but, clearly, the problem will reappear. An infinite descending hierarchy of moral facts is incompatible with the idea that morality has a grounding ${ }^{10}$ - just as an infinite descending hierarchy of turtles is incompatible with the idea that the ground has a grounding. ${ }^{11}$

Perhaps a bigger problem, given our purposes, with maintaining that God is the source of DCT is that this strategy does not generalize to the other, more common forms of constructivism. Contractarian constructivists, for instance, presumably do not want to be committed to the idea that, among the rules of morality that the hypothetical contractors would choose is the contractarian principle itself. Likewise, sentimentalists presumably do not

${ }^{10}$ If this claim needs an argument, here is one. Consider the big conjunction of all the members of the infinite chain of moral facts. This, too, is a moral fact (a conjunction each of whose conjuncts is a moral fact is itself a moral fact). This conjunction will have no ground and will thus be an ungrounded moral fact. God can try to ground it, but, as argued above, corresponding to this act of attempted grounding will be a new moral principle (a corresponding meta-DCT), which itself, not God, is technically the ground of the infinite conjunction (recall that our grounding relation here relates truths to truths, not truths to concrete particulars like God). This new principle will have no ground.

11 Although I do not want to dwell too long on the theistic case, since my aims are broader, it might be worth briefly addressing a few further, related possibilities. One is to ground DCT in the more general principle that if God declares that something is the case, then, and in virtue of that, it is the case (together with the claim that God has declared that DCT is the case). But even this principle, too, has moral content, since its universal quantifier ranges over moral truths. Stated more fully, it is saying that for any proposition - including moral propositions - if God declares that it is true, then it is true. Nor will it help to say that things have their moral features, such as being good, in virtue of their resemblance to God. The brute moral truth on this (anyway realist) theory is the truth that God is good.

Mark Murphy identifies a version of the divine command theory according to which, he claims, "no normative states of affairs obtain prior to God's willing" (1998: 11). This theory "explains the existence of particular moral requirements simply in terms of God's power to actualize normative states of affairs" (ibid.). Murphy is right that, on this theory, no particular normative states of affairs obtain prior to God's willing. But prior to God's willing any particular normative states of affairs to obtain, a fact of the following general sort must be true: If God wills that promises should be kept, then promises should, in virtue of that, be kept. The claim that God has the power to actualize normative states of affairs surely requires this conditional claim to be true. But this conditional claim is a moral claim, analogous to the Rossian principle. 
want to be committed to the idea that, among the things that we approve of, is the sentimentalist theory itself. ${ }^{12}$

Another attempt to construct the divine constructivist theory itself appeals not to a different, higher-level constructivist principle (such as mDCT) but, in the spirit of pulling oneself up by one's own bootstraps, to the very principle one is trying to construct. One could try to maintain that DCT's source is found not in the things God declares, as in the previous proposal, but in the things God commands, a phenomenon governed by DCT itself. The thought would be that just as God has commanded us to keep our promises, he has commanded us to do whatever he commands. Morality requires us to abide by the Rossian principle because God has commanded us to keep our promises, and morality requires us to do whatever God has commanded us to do (in other words, the DCT is true) because God has further commanded us to follow his commands.

But this kind of circularity is surely vicious. The truth of DCT is here grounded in the fact that God has commanded us to follow his commands. And this matters - that is, that God has commanded something gives rise to an obligation to do it - because DCT is true. But this circle is too tight to make for a genuine explanation. And even if some explanatory contexts would allow it, we are anyway here inquiring into the sort of explanation constituted by a kind of metaphysical grounding, and this metaphysical grounding, whatever else it is, is an asymmetric relation. If $\mathrm{Q}$ is true in virtue of $\mathrm{P}, \mathrm{P}$ cannot also be true in virtue of $\mathrm{Q} \cdot{ }^{13}$

12 Even if this were true in the sentimentalist case, it is not clear that it would help, since sentimentalism says that, say, a trait of character is a virtue iff, and because, we approve of it. They do not say that some truths are true because we approve of the truths.

13 Some opponents of this theistic strategy may want to appeal here to an analogy with Satan, noting that the fact that Satan has commanded us to follow his commands does not seem to give rise to an obligation to follow them. But I am not sure this is relevant. That Satan's commands do not give rise to obligations may simply be due to the fact that the Satanic command theory is not true. What we are doing above, however, is granting that the DCT is true, and then inquiring into whether it might have a nonmoral ground. We are assuming that God's commands do give rise to moral obligations, and then asking what makes that moral fact - the fact that God's commands give rise to moral obligations - true.

The circularity charge here (in the main text) may be the same charge made by Cudworth (1731, ch. 2, \ 3) against theories like DCT. As Mark Schroeder (2005: 3) summarizes it,

Cudworth's claim is ... that a command like this [a command by God that we do whatever he commands] cannot be what explains why you ought to do what God commands. For according to Cudworth, that would already have to be true, in order to have such an effect.

However, to be sure, unlike Cudworth, it is not my aim here to be arguing against DCT, but rather against the idea that the divine command theorist can provide an explanation for all moral facts. The divine command theorist can, at least coherently, avoid Cudworth's argument by taking the fact that we ought to do what God commands to be a brute and inexplicable moral fact. 
Finally, constructivists can of course concede that while they can explain where all workaday moral facts come from, they cannot provide a source for their fundamental principle of morality, and must accept it as a groundless, unconstructed moral truth. I think that this is indeed what constructivists should say. Craig should agree that on his picture too at least one moral value would be ungrounded. And Shafer-Landau should not let his constructivist rivals off so easily, as they too have no answer to the question of what makes their fundamental moral principle true; they in fact cannot point to some person(s), actual or idealized, whose attitudes are responsible for fixing this truth.

But then the advantage in kind over realism is lost. Constructivism will differ from the robust pluralist realism of Ross at most only in degree (in positing fewer brute moral facts), and will differ from other realist views (such as a view that puts forth utilitarianism as the single, fundamental moral principle) not even in degree.

The same sort of thing will be true in the debate over the source of practical reasons. Goldman is correct that "the externalist can provide no explanation of objective values (they are simply brute normative facts)" (2006: 484). But nor can internalists provide explanations for all normative facts. Internalists cannot explain internalism itself, or why, when a person has a desire to do something, this generates a reason for him to do it. For an internalist, this too is simply a brute normative fact. ${ }^{14}$

\section{Can reductionism help?}

Shafer-Landau goes on to qualify the original objection to realism, suggesting that it applies only to nonreductive realists (of which he is one):

If some standard is true, irreducible, and to be construed realistically, then nothing makes it true; its truth is not a creation, but instead a brute fact about the way the world works (2003: 48, first emphasis added).

But

If moral standards are reducible ... and if realists can satisfactorily account for the reduction, then they have an adequate explanation of the status of the moral standards (2003: 47, emphases altered).

In a similar vein, Matthew Evans and Nishi Shah (forthcoming) write that the problem with nonreductionism, according to both the constructivist and the reductionist,

is that it is committed to there being at least some normative facts at the bedrock level of explanation. This commitment is widely held to be naïve at best, and

14 Some of the ideas in this section share some points of contact with Wielenberg 2009. 
childish at worst: a holdover from some earlier, less enlightened vision of the uni-

verse.

All three philosophers here have in mind the idea that if morality is reducible to something nonmoral, then morality will have a complete nonmoral source. Morality will be grounded in whatever nonmoral phenomena it reduces to. There will be no normative facts at the bedrock level of explanation. In what follows, I want to explain why it seems that not even reductionism (which comes in both realist and constructivist varieties) delivers a complete grounding for morality. Even if morality is reducible, there will still be brute moral facts. Since reductionism in ethics is surely the best hope for the view that all of morality can be explained, if even it cannot deliver this result, we can conclude that the task cannot be done. ${ }^{15}$

Reductionism in metaethics is the idea that, to put it rather roughly, the moral just is something else. ${ }^{16}$ Moral properties are identical to properties from some other domain. To be morally wrong, for example, just is to have some property that we can express using nonmoral terms - such as the property of being generally disapproved of or the property of failing to maximize happiness. ${ }^{17}$ Such theories will be able to take their chains of explanations of moral phenomena further than did Rossian realism or our divine-based constructivism. These two views stopped the explanation at a moral principle in the familiar form of a (grounding) conditional. But reductionist views believe in an underlying identification of the moral and the nonmoral, to which they can appeal to explain their conditional-form moral principles. ${ }^{18}$

Consider, for example, David Lewis' (1989) theory that something is a value if and only if we would be disposed, under ideal conditions, to desire to desire it. Because Lewis advances this theory as a reduction of value, he holds not only that there is this necessary covariance between the properties of being a value and being something we would desire to desire, but that these are one and the same property. That is, he holds that to be a value just is to be something we would desire to desire. This identity claim, it is plausible to say, is what makes the biconditional principle above true. ${ }^{19}$ Ross' principle about promises enjoys no such grounding in Ross' system.

15 Shafer-Landau mentions in passing that perhaps even the reductionist will leave something relevant unexplained: their very reduction of the moral to the nonmoral (2003: n. 47). I believe that is exactly right.

${ }^{16}$ Hence the epigraph, due to Butler (1765: xxvii), of Moore's anti-reductionist Principia Ethi$c a$ : "Every thing is what it is and not another thing."

17 Though there must be more to being a reductionist than believing in such an identity, since reduction is supposed to be an asymmetric relation whereas identity is symmetric.

18 This general kind of explanation - one from a reductive identity thesis to conditional-form moral principles - is discussed in Schroeder (2005: 17-23 and passim).

${ }_{19}$ It should be noted that, as accords with my earlier thesis, this strategy is not proprietary. A realist who is also a reductionist can provide a source for her main principle in the same fashion. However, it admittedly might be the case that reductionism is more defensible given some forms of constructivism than given realism. This is because the nonmoral facts to 
But even a reductionist theory of value such as this seems not to provide a grounding for all evaluative truths. For we can now ask about the very identity statement that is grounding the biconditional principle. Is it, too, a moral claim, and, if so, what explains it?

I believe that the identity claim, like the biconditional principle it grounds, is a moral or evaluative claim. (i) It immediately and obviously entails (together with some empirical facts) all sorts of claims that are uncontroversially evaluative (such as that honesty is a value). (ii) It can play the same sort of role that the uncontroversially moral Rossian principle above can play in explaining which particular things have which moral features. (iii) Anyone who asserts that what it is to be valuable is to be something we would desire to desire would surely seem to be taking an evaluative stand; we would not take such a claim to be morally neutral. (iv) This identity claim about the property of being a value is not the sort of claim that a moral nihilist could accept. (v) We have an intuitive grasp of when statements fall on the ought side (or value side) or Hume's is-ought (or fact-value) divide, and we would surely put the claim that to be valuable just is to be something we would desire to desire on the value side. Finally, (vi) compare it to the identity claim that to be a sensation of pain is to be a c-fiber firing, which we would classify as a claim about the mind, a mental claim. All of this suggests that the identity claim that to be valuable is to be something we would desire to desire is itself a claim about value, an evaluative claim. ${ }^{20}$

I do not intend here to be offering a general criterion of what makes a statement a moral statement. I am relying rather on our intuitive judgments about what sorts of factors serve as evidence that a statement is a moral statement. The considerations above, I believe, provide very good evidence that the claim that to be valuable just is to be something we would desire to desire is an evaluative claim.

which moral facts reduce on constructivist theories, or at least on those constructivist theories that ground moral facts in facts about attitudes that motivate action, may thereby lose less of the normative force had by moral facts. Reductions are better that capture more of our preconceptions of the reduced phenomena. See Heathwood 2011: 84-86.

20 Dworkin (1996: 101) makes a similar point:

There is no difference in what two people think if one thinks that the only thing that can make an act right is its maximizing power, so that it makes no sense to evaluate rightness in any other way, and the other thinks that the property of rightness and the property of maximizing power are the very same property. The second opinion uses the jargon of metaphysics, but it cannot add any genuine idea to the first, or subtract any from it. It sounds more philosophical but it is no less evaluative.

For the record, I would disagree that there is no difference in what these two people think. The first might be a nonreductionist about rightness, while the second a reductionist about rightness. These are different views. But I agree that the reductionist thesis - the identity claim - is no less evaluative that the corresponding claim about what makes an act right. 
So what, then, of this evaluative fact (assuming it is a fact) that to be valuable just is to be something we would desire to desire? Does it have a source? To help us answer this, we can consider a neutral analogy: the claim that to be a triangle just is to be a three-sided polygon. This is one of the truths of geometry, just as Lewis' claim (if true) is one of the truths of ethics. In virtue of what is it true that to be a triangle is to be a three-sided polygon?

Here is one tempting answer: This is true because that is just what the word "triangle" means. That is, the word "triangle" and the expression "three-sided polygon" mean the same thing, and this is what makes it true that to be a triangle just is to be a three-sided polygon.

Interestingly, if such an answer is successful in the triangle case, Lewis could embrace the analogous answer in the value case, since he believes that his theory of value is not just true, but analytically true (which is why I chose his view for our example) (1989: 129). Thus, Lewis holds that the expressions "is a value" and "is something we would desire to desire" simply mean the same thing. An advocate of Lewis' view might then offer this claim about meaning as a source for Lewis' principle. Even more interesting, if such an answer were correct, morality could have a complete source. For the claim that the expressions "is a value" and "is something we would desire to desire" mean the same thing is evidently not a moral or evaluative claim. It is simply a linguistic claim, a claim that two different strings of symbols have the same meaning in English. Of course, many are doubtful that any form of analytic reductionism is true of any normative or evaluative notion. But that is not relevant here. For I am trying to argue that morality would not have a source even on a reductionist view, including analytic reductionism - arguably the "most reductionist" of reductionisms.

This strategy of explaining the truth of these identity statements by appeal to the meaning of words is not promising, however. The explanations simply fail. For these truths are not made true by the meaning of words. If there had never been any words, or if our words had all had different meanings, it still would have been true (speaking here in English as it actually is) that to be a triangle just is to be a three-sided polygon. And it still would have been true that to be a value just is to be something we would desire to desire. These truths cannot be explained by what certain words mean because their truth does not depend upon what any words mean. They will be true no matter what any words mean (though of course, if all our words had different meanings, we would use different words to express these same truths). It might be that we can explain why the sentence "To be a triangle just is to be a three-sided polygon" is true by appealing to what certain words mean. But such claims about sentences and words would seem to have no bearing on what grounds the truths that these sentences express, which is our topic here.

A second natural answer to the question, "What makes it true that to be a triangle just is to be a three-sided polygon?" is something like this: That is just the nature of triangles; that is just what it is to be a triangle. But this is not a good answer either. It simply reasserts what the question wanted ex- 
plained. What makes it true that to be a triangle just is to be a three-sided polygon cannot be that to be a triangle just is to be a three-sided polygon. Nothing makes itself true. ${ }^{21}$ Indeed, that this answer is a natural one to give is itself evidence that it is a brute truth after all that to be a triangle is to be a three-sided polygon.

This answer - that nothing makes it true that to be a triangle is to be a three-sided polygon - might very well be the correct one. It might be a brute fact, a fact unexplainable by appeal to any other fact, that to be a triangle is to be a three-sided polygon. If this is a brute fact, then it would seem that so is the fact (assuming it is a fact) that to be a value just is to be something we would desire to desire. We would thus have arrived at our brute moral truth, even on the reductionist picture.

Consider again the Rossian principle that if a person has made a promise, she has, in virtue of that, a prima facie obligation to keep it. Ross would deny that this is a reductive principle. He believes that there are moral properties, that there are nonmoral properties, and that while moral properties always obtain in virtue of the obtaining of nonmoral properties, no moral property is ever identical to any nonmoral property (that is, identical to any property that we can express using nonmoral terms). There is necessary dependence without identity. But Ross could probably agree that it is at least "of the nature" of prima facie moral obligation that if a person has made a promise to perform some act, then that person is, in virtue of that, under a prima facie moral obligation to do it. He might not want to say this it is part of the nature of prima facie moral obligation, since this might suggest something Ross denies: that prima facie moral obligation is, as Lewis thinks value is, a complex property admitting of parts, and reducible to them (Ross 1930: 12, passim). But Lewis and Ross ought to agree about what concerns us here: that their respective most fundamental moral claims have no grounding.

To say that ethical reductionism cannot provide a source for all moral facts is of course not to say that there are no benefits to being an ethical reductionist. Identifying moral properties with nonmoral properties enjoys all manner of advantages..$^{22}$ My point here is simply that reductionism is of no help in providing a complete nonmoral grounding for all moral facts.

There might seem to be an important difference between the sort of brute moral truths the reductionist must appeal to and the sort that nonreductionists are committed to. Lewis' brute truth - that to be a value is to be something we would desire to desire - it might be thought, is trivial. For if his

21 Perhaps in some contexts we would count answers like the one discussed here as genuine explanations. Perhaps on one legitimate notion of explanation, anything that (rationally) removes puzzlement in inquirers counts as a successful explanation. But this does not hold for what concerns us here: the kind of explanation involved in claims of metaphysical grounding between truths.

22 For example, accurately identifying moral properties with nonmoral properties reveals the nature of moral properties, explains the supervenience of the moral on the nonmoral, and can help explain how we can know moral facts. See Heathwood (forthcoming). 
view is right, then this truth would seem to be the same truth as the obviously trivial truth that to be something we would desire to desire is to be something we would desire to desire. The Rossian principle, by contrast, is substantive. There is, on Ross' system, no trivial truth to which it is identical. And perhaps it is worse to be stuck with substantive brute moral claims than it is to be stuck with trivial brute moral claims.

I have two responses to this point. First, even if Lewis' theory that to be a value is to be something we would desire to desire is analytic, this does not seem to show that it is trivial. Many analyticities are trivial truths, but the ones that interest philosophers - e.g., the true analyses of knowledge, or causation, or value - require difficult work to discover. Lewis' theory, if true, is a rather monumental discovery, not a truism. ${ }^{23}$ Second, even if there is some sense of "trivial" in which any analytic reduction is trivial, and, furthermore, this sort of triviality is one that makes a brute truth more acceptable, my main point - that not all moral truths can be explained - is not undermined. It would be interesting if reductionism's primitive truths were easier to accept than those of nonreductionism, but this would not change the fact that each approach must accept some moral truths as brute.

We should briefly consider a third possible answer to the question, "In virtue of what is it true that to be a triangle is to be a three-sided polygon?" namely, that the property of being a triangle has, as its only two parts, the properties of being a polygon and being three-sided. ${ }^{24}$ Perhaps this claim provides a grounding for the identity claim about triangles. But notice that we will not have grounded the geometrical fact that to be a triangle is to be a three-sided polygon in a nongeometrical fact. For the claim that the property of being a triangle is composed of the properties of being a polygon and being three-sided is no less a fact of geometry. Thus, even if an analogous answer will hold in the moral case, then while this may provide a source for the moral identity claim, it will not be a nonmoral source. The truth that the property of being a value is composed of the properties of desiring to desire, etc., would likewise be an evaluative truth. It "uses the jargon of metaphysics ... It sounds more philosophical but it is no less evaluative" (Dworkin 1996: 101). 25

23 It may be worth noting that Lewis himself does not regard his theory to be trivial: "The equivalence between value and what we are disposed to value is meant to be a piece of philosophical analysis, therefore analytic. But of course it is not obviously analytic; it is not even obviously true" (1989: 129). There remains the puzzle of how there could be true but nontrivial analyses; this is not the place, however, to try to solve the so-called paradox of analysis.

${ }^{24}$ Cf. Schroeder 2007, ch. 4. The proposal as stated above might be too simplistic. We may also need to say something to the effect that these parts have to be arranged in a certain way (viz., they have to be related by conjunction) in order to compose the property of being a triangle. There is also the issue that being three-sided and being a polygon may themselves have parts.

25 On another kind of reductionism, the fundamental principles linking the moral to the nonmoral are not identity claims but constitution claims (see Brink 1989: 156-59). The same 


\section{Concluding remarks}

The claim that morality could not have a source - that some moral facts must be ungrounded - is not just the same as Hume's claim that one cannot derive an ought from an is. Hume's law is, I take it, a claim about the legitimacy or validity of drawing certain inferences. As such, it is either a normative claim of epistemology or rationality, or a claim of logic. But our topic here is one in metaphysics: about what grounds certain kinds of truth. That some truth is made true by another truth can of course be involved in a valid inference from one to the other. But this is not the only way to make for a valid inference, and, even in the cases in which this is what makes for some valid inference, the metaphysical fact of grounding is itself prior to, and would explain, the fact of the validity of the inference. There are certainly epistemic objections to moral realism that relate to Hume's law, but there is also a separate "source" or grounding objection to moral realism, which has been my concern here. 26

The claim that morality could not have a source is like an instance of the familiar idea that explanation must come to an end somewhere. But I do not think that makes it uninteresting. One might think that it does make it uninteresting because we all agree that explanation must stop somewhere, and so the claim that it does, along with its obvious implications, are rather uninteresting truths. But I do not think the claim that there are brute moral truths is an obvious implication of the claim that all explanation must stop somewhere. Initially, one might have thought that along all of the chains of explanation that there are, we will find the most basic moral truths appearing somewhere in the middle of a chain and never at the beginning of one. Indeed, Evans and Shah suggest that this is a core commitment of most kinds of metaethical theory (here I partly repeat a passage quoted earlier):

And the problem with primitivism [i.e., nonreductive realism], according to both the anti-realist and the reductivist, is that it is committed to there being at least some normative facts at the bedrock level of explanation. This commitment is widely held to be naïve at best, and childish at worst: a holdover from some earlier, less enlightened vision of the universe.

The core conviction of every anti-realist, then, is that the best available metanormative theory has no room for normative facts that cannot be explained by some appropriate body of non-normative, attitudinal facts. The constructivist, the expressivist, and the error theorist all share this conviction (Evans and Shah forthcoming).

reasons for thinking that identity claims linking the moral to the nonmoral are themselves moral claims apply to constitution claims linking the moral to the nonmoral.

${ }^{26}$ Nor is our topic the question, "Why be moral?" or the related question of the normativity of moral requirements (Foot 1972, Korsgaard 1996). Even if there are no reasons to be moral, we can still ask, "Given that it is true that I morally ought to do such-and-such, what makes this true?" or, more generally, "Given that M is a moral truth, what makes it true?" 
I have tried to explain why we should doubt that this picture is correct. It seems that there must always be at least one moral "bridge principle" (whether a grounding conditional, an identity claim, a claim about property structure, or a constitution claim) bridging the nonmoral to the moral, and that this principle must be fundamental.

It is an implication of the view defended here that there may be many more brute facts than one might have thought. Indeed, for any category of truths (biological truths, historical truths, golf-related truths), there may be brute truths in that category. Thus, it may be that the sense in which not all moral facts have a source is the same sense in which, say, not all legal facts have a source. Of course, there will be sources for all workaday legal facts such as that jaywalking is illegal in Los Angeles. But, for the reasons sketched earlier, there may be no source for the most fundamental truths concerning the notion of legality, such as that what it is for there to be a law in some jurisdiction that prohibits some act just is for such-and-such conditions to hold. It will just be part of the nature of legality that this principle holds.

However, perhaps not all domains will after all have brute facts in this way. A relevant difference between ethical facts and some other classes of fact is that for ethical facts, the fundamental bridge principle is clearly itself also a fact within ethics, while for some other domains, this may not be true. It is a legal claim that jaywalking is illegal in Los Angeles. But it is less clear that the claim about the nature of illegality in Los Angeles itself - the claim of form " $\mathrm{x}$ is illegal in Los Angeles iff, and because, ___ - is also a claim about the law. Lawyers do not need to know that - philosophers of law do. Similarly, while historians need to know which important events occurred in the past, they do not need to know what it is for an important event to have occurred in the past (that is partly a question in the philosophy of time). But complete experts in ethics need to know not only which acts are right, but what it is for an act to be right, and what explains any act's being right. There is no field "philosophy of ethics" - that is just ethics.

Most of us agree that constructivism is true of legality, in the sense that properties like being against the law in Los Angeles are stance-dependent properties. And we would continue to maintain this even if we learned that there were brute legal facts. Thus I am not saying that the fact that morality could not have a source undermines constructivist theories about morality. Rather, I am saying, in part, that the fact that moral realism provides no source for morality is no problem for it. Constructivists should admit that their fundamental moral principle is an unconstructed moral truth. If some constructivists have been driven to constructivism in order to avoid any unconstructed moral truths, then I do take myself to be undermining this reason for being a constructivist. But there are other reasons to be a constructivist. ${ }^{27}$ And there

27 Philosophers are attracted to constructivism by considerations of moral disagreement, to accommodate motivational internalism, over doubts about objective evaluative properties, from evolutionary considerations, and other reasons. 
can still be a distinction between realism and constructivism even if both views recognize unconstructed moral truths: Constructivism holds that moral properties are stance dependent, while realism does not. But constructivism, even reductionist forms of it, cannot construct all of morality. Not all moral truths can have a source. 28

Chris Heathwood

University of Colorado at Boulder

Department of Philosophy

heathwood@colorado.edu

${ }_{28}$ Versions of this paper were presented at the 62nd Annual Mountain-Plains Philosophy Conference; the Center for Values and Social Policy at the University of Colorado at Boulder; the Stockholm June Workshop in Philosophy; Bowling Green State University; the 2011 Pacific Division Meeting of the American Philosophical Association; and the first annual SDSU Stephen L. Weber Graduate Conference in Ethics. For helping me improve the paper, I am grateful to the audiences at these events, to commentators Franz-Peter Griesmaier and Robert Gressis, and to the following people: David Barnett, David Boonin, Richard Chappell, Eric Chwang, Christian Coons, Dale Dorsey, David Faraci, Amanda Greene, Jens Johansson, Kathrin Koslicki, Christian Lee, Uri Leibowitz, Kris McDaniel, Wes Morriston, Jonas Olson, Jason Raibley, Michael Rubin, Rob Rupert, Jonathan Schaffer, Brian Talbot, Pekka Väyrynen, Erik Wielenberg, and two anonymous referees for this journal. 


\section{References}

Adams, Robert M. (1999) Finite and Infinite Goods, Oxford: Oxford University Press.

Brandt, Richard B. (1979) A Theory of the Good and the Right, Oxford: Clarendon Press.

Brink, David (1989) Moral Realism and the Foundations of Ethics, Cambridge: Cambridge University Press.

Butler, Joseph (1765) Fifteen Sermons Preached at the Rolls Chapel, London: Robert Horsfield.

Clarke, Samuel (1732) A Discourse Concerning the Being and Attributes of God, the Obligations of Natural Religion, and the Truth and Certainty of the Christian Revelation, Eighth Edition, London: J \& J Knapton.

Correia, Fabrice (2008) “Ontological Dependence,” Philosophy Compass 3: 1013-32.

Craig, William Lane and Sinnott-Armstrong, Walter (2004) God?: A Debate Between a Christian and an Atheist, Oxford: Oxford University Press.

Cudworth, Ralph (1731) A Treatise Concerning Eternal and Immutable Morality, London: J \& J Knapton.

Denis, Lara (2008) "Kant and Hume on Morality," in Edward N. Zalta, ed., The Stanford Encyclopedia of Philosophy, Summer 2008 Edition, http://plato.stanford.edu/archives/ sum2008/entries/kant-hume-morality.

Dworkin, Ronald (1996) “Objectivity and Truth: You'd Better Believe It," Philosophy and Public Affairs 25: 87-139.

Evans, Matthew and Shah, Nishi (forthcoming) "Mental Agency and Metaethics," Oxford Studies in Metaetbics 7.

Firth, Roderick (1952) "Ethical Absolutism and the Ideal Observer Theory," Philosophy and Phenomenological Research 12: 317-45.

Foot, Philippa (1972) "Morality as a System of Hypothetical Imperatives," Philosophical Review 81: 305-16.

Heathwood, Chris (forthcoming) "Reductionism in Ethics," in H. LaFollette, ed., The International Encyclopedia of Ethics, Wiley-Blackwell.

(2011) "Desire-Based Theories of Reasons, Pleasure, and Welfare," Oxford Studies in Metaethics 6: 79-106.

Goldman, Alan (2006) "Desire Based Reasons and Reasons for Desires," Southern Journal of Philosophy 44: 469-88.

Huemer, Michael (2005) Ethical Intuitionism, New York: Palgrave.

Korsgaard, Christine (1996) The Sources of Normativity, Cambridge: Cambridge University Press.

Lewis, David (1989) "Dispositional Theories of Value," Proceedings of the Aristotelian Society, Supplementary Volume 63: 113-37.

Locke, John (1690) Essay Concerning Human Understanding.

Milo, Ronald (1995) “Contractarian Constructivism," Journal of Philosophy 92: 181-204.

Murphy, Mark C. (1998) "Divine Command, Divine Will, and Moral Obligation," Faith and Philosophy 15: 3-27.

Parfit, Derek (2001) "Rationality and Reasons," in D. Egonsson, J. Josefsson, B. Peterson and T. Rønnow-Rasmussen, eds., Exploring Practical Philosophy: From Action to Values, Aldershot: Ashgate Publishing, pp. 17-39.

Price, Richard (1787) A Review of the Principal Questions in Morals, Third Edition, London: T. Cadell.

Quinn, Warren (1993) "Putting Rationality in Its Place," in W. Quinn, Morality and Action, Cambridge: Cambridge University Press, pp. 228-55.

Ross, W. D. (1930) The Right and the Good, Oxford: Clarendon Press.

Schroeder, Mark (2005) "Cudworth and Normative Explanations," Journal of Ethics \& Social Philosophy 1: 1-27. (2007) Slaves of the Passions, Oxford: Oxford University Press.

Shafer-Landau, Russ (2003) Moral Realism: A Defence, Oxford: Oxford University Press. 
Wielenberg, Erik J. (2009) "In Defense of Non-Natural, Non-Theistic Moral Realism," Faith and Philosophy 26: 23-41.

Williams, Bernard (1981) "Internal and External Reasons," in B. Williams, Moral Luck, Cambridge: Cambridge University Press, pp. 101-13. 